\title{
23. GLASSY OBJECTS IN DEEP SEA CLAYS
}

\author{
C. C. von der Borch \\ Scripps Institution of Oceanography, La Jolla, California
}

During coarse-fraction (>62 microns) studies on Leg 5 samples, dark colored glassy objects resembling microtektites or small lapilli were found in some cores. These objects occur in Tertiary deep-sea clay deposits at Site 32. A single example of a clear glassy spherule containing bubble cavities was found in near-surface sediments at Site 37 . The superficial similarity of the above material to microtektites described from deepsea sediments by Glass $(1967,1968)$ makes it desirable to discuss the occurrences in some detail.

Table 1 indicates Leg 5 samples from which the unusual glassy objects have been described. In the material studied, it is apparent that they invariably occur in deep-sea clays, associated with zeolites (phillipsite), scattered shards and traces of mica and feldspar. The single clear spherule collected at Site 37 was from a deep-sea clay containing abundant manganese micronodules. Fish debris and possible faecal pellets are ubiquitous associates in the coarse fractions and rare magnetite octahedra were noted at Site 32, Core 11, Section 2. The most prolific occurrence of these objects is at Site 32 in sediments of lower to middle Tertiary age where they occur throughout a zone at least 20 meters in thickness.

The age of the sediment associated with the Site 32 samples lies between lower Miocene and lower-upper Oligocene. The single example of a clear glassy sphere occurred in sediment of upper Pliocene age.

Plate 1 illustrates shapes most commonly encountered. Spheres are by far the most common shape (Plate 1, Figure 1); teardrops are also fairly abundant (Figure 1). Dumbbells (Figure 2) appear to be rare, as are reniform shapes (Figure 3) and rounded cylinders (Figure 1). The single example of a translucent bottle-green elongate teardrop is also illustrated (Figure 4). Aerodynamic tektite-like disks are not apparent. Sizes vary from 0.3 up to 1.2 millimeters, with no obvious examples occurring in the $<62$-micron fraction. Irregular darkcolored glassy and stony vesicular fragments, usually associated with the above material, are not shown in the illustration.

External surfaces vary from smooth and highly glossy to rough and dull. Some samples show an external slag-like spattering of small globules, while spherical and cylindrical types commonly have small protrusion suggesting former attachments. The short teardrop varieties appear to have formed by the breaking apart of spinning dumbbells while these were in a molten stage. Broken surfaces appear glassy and exhibit a conchoidal style of fracture. Samples which possess dull exterior surfaces invariably have thin de-vitrified crusts surrounding vitreous interiors. Spherical bubble cavities are common and some of the spheres are essentially hollow.

The bulk of the glassy objects described from Site 32 are dark brown to black in color and translucent to opaque. Only one example was found which was a clear bottle-green color, and one which was completely colorless. All the dark-colored samples have high magnetic susceptibilities. When powdered, they are seen to consist of a translucent greenish-brown glass with refractive index ranging from 1.60 to 1.61 . X-ray diffraction studies indicate the presence of possible calcic plagioclase and clinopyroxene, both of which must be present as crystallites within the glass. Olivine and magnetite are not apparent in the limited number of diffractograms taken. The minerology, along with the refractive index, suggests a composition equivalent to that of basaltic glass.

Because the glassy objects from Sites 32 and 37 have many properties in common with microtektites described by Glass $(1967,1968)$, it is pertinent at this point to discuss some of the similarities and differences. Glass describes microtektites from deep-sea cores taken in the Australian Basin (southeastern Indian Ocean) and Wharton Basin (eastern Indian Ocean) as well as from near the Ivory Coast (eastern Atlantic). In these examples, the glassy objects were found to occur in a variety of sediments, including tan-colored foraminiferal lutite, brown lutite and tan silty lutite. In all cases, the objects appear concentrated in the vicinity of the last magnetic reversal, as determined by magnetrometer studies on undisturbed core samples. This suggests that they are about 0.7 million years old, and may be microtektites related to the Australian tektite strewn field. Spherical shapes dominate the samples described by Glass. Their colors range in different areas from almost colorless to greenish yellow, bottle-green and dark yellowish-brown, with the dark-colored type showing appreciable magnetic susceptibility. Refractive indices range from 1.50 
Plate 1

Photomicrographs of typical samples of glassy objects from Site 32

Figure 1 An assortment of teardrop, rounded cylindrical and spherical shapes. Note glossy surface of sphere and small projection. (Diameter of sphere $0.4 \mathrm{~mm}$ )

Figure 2 Dumbbell form (Length $0.8 \mathrm{~mm}$ )

Figure 3 Reniform shapes. Note slaggy exteriors. (Length $0.7 \mathrm{~mm}$ )

Figure $4 \quad$ Fragile translucent green teardrop (Length $0.6 \mathrm{~mm})$ 


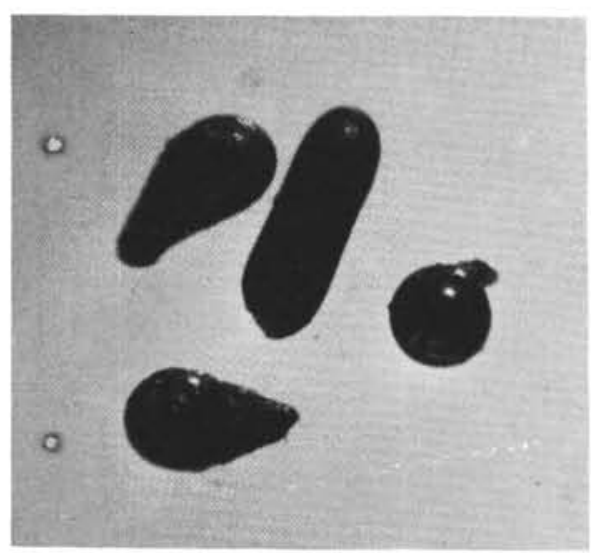

Figure 1

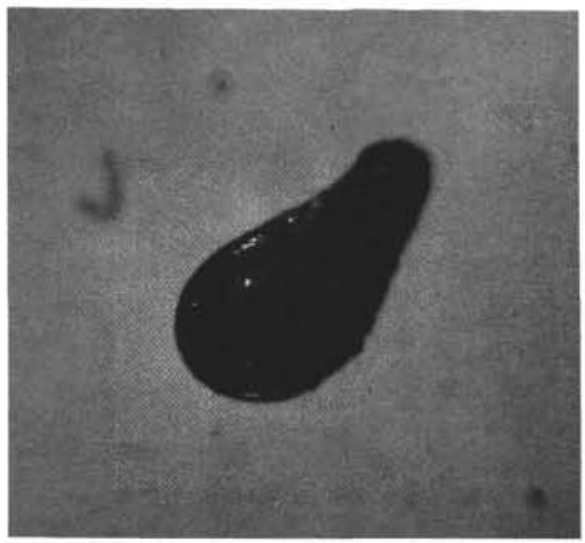

Figure 3

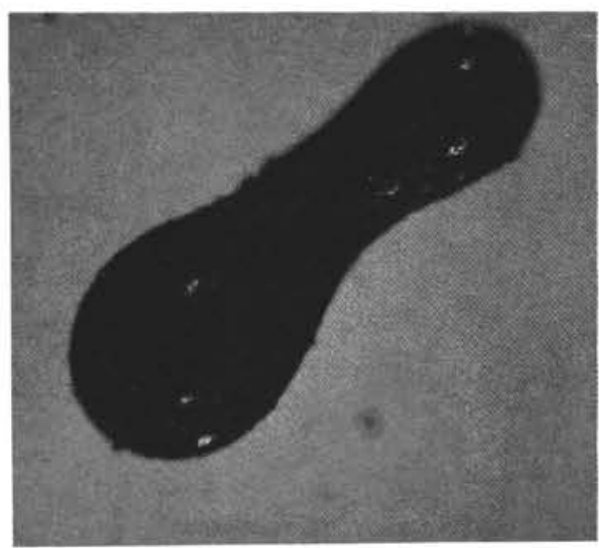

Figure 2

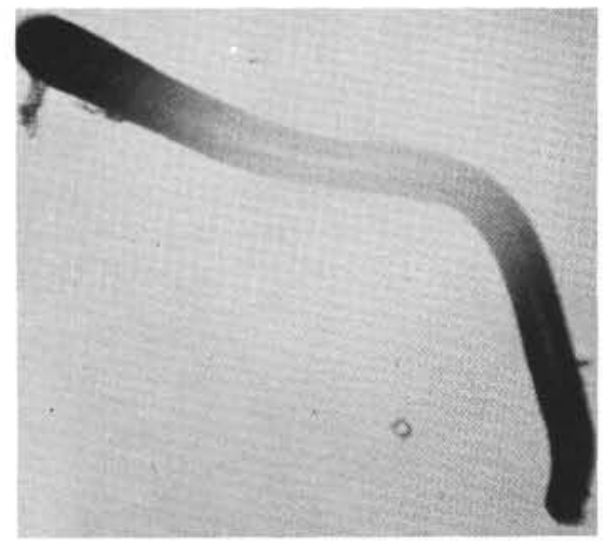

Figure 4

Plate 1 
TABLE 1

Leg 5 Sediments Containing Glassy Objects in $>62 \mu$ Fraction

\begin{tabular}{|c|c|c|c|c|c|c|c|}
\hline Site & Core & Section & $\begin{array}{l}\text { Depth } \\
\text { (cm) }\end{array}$ & Sediment Type & Description of Object & Quantity $^{\mathrm{a}}$ & Age \\
\hline 32 & 10 & 2 & $17-19$ & Red clay, tr. glass & Spheres, dumbbells, droplets & a & \multirow{5}{*}{$\begin{array}{l}\text { Between lower } \\
\text { Miocene and } \\
\text { lower-upper } \\
\text { Oligocene }\end{array}$} \\
\hline 32 & 10 & 3 & $20-22$ & Red clay, tr. glass & Spheres, droplets, irreg. frags. & c & \\
\hline 32 & 11 & 1 & 114 & Red clay, zeolite, altered ash & Spheres, droplets, irreg. frags. & $\mathrm{c}$ & \\
\hline 32 & 11 & 2 & $8-10$ & Red clay, zeolite, altered ash & Spheres, droplets, irreg frags. & $\mathrm{r}$ & \\
\hline 32 & 11 & 3 & $17-19$ & Red clay, zeolite, altered ash & Spheres, bottle-green teardrop & $\mathrm{r}$ & \\
\hline 32 & 12 & 1 & $78-81$ & Red clay, altered ash beds & Spheres, irreg. frags. & $\mathrm{r}$ & \multirow{3}{*}{$\begin{array}{l}\text { Lower-upper } \\
\text { Oligocene }\end{array}$} \\
\hline 32 & 12 & 2 & $10-12$ & Red clay, altered ash beds & Spheres & $\mathrm{r}$ & \\
\hline 32 & 12 & 6 & $5-7$ & Red clay, altered ash beds & Black vesicular frags. & $\mathrm{r}$ & \\
\hline 37 & 1 & 3 & $1-3$ & Red clay, Mn. micronodules & Clear glassy sphere & $\mathrm{r}$ & Upper Pliocene \\
\hline
\end{tabular}

${ }^{\mathrm{a}} \mathrm{a}=$ abundant, $\mathrm{c}=$ common, $\mathrm{r}=$ rare. 
to 1.62 , depending on color and locality. Sizes vary from in excess of 1 millimeter down to 38 microns. Surface textures vary from glassy smooth to badly pitted. Spherical bubble cavities are common.

From the foregoing discussion, it is apparent that the glassy objects of Sites 32 and 37 of the Deep Sea Drilling Project have many properties in common with microtektites described by Glass. It does appear that the Deep Sea Drilling material is, on an overall basis, darker in color and higher in refractive index than the microtektites of Glass. It is also associated with considerable amounts of what may be small fragments of vesicular basalt and scoriaceous glass. The magnetic stratigraphy of the Deep Sea Drilling cores at Site 32 has not been determined-due to core disturbancesso, it is not known whether the apparently isolated influx of glassy objects is associated with a Tertiary magnetic reversal.

At this stage it is uncertain whether the glassy objects collected at Site 32 of the Deep Sea Drilling Project are microtektites, related to a cosmic phenomenon, or whether they are microlapilli of volcanic origin. Electron microprobe studies are currently in progress and these results may throw light on their genesis. However, in view of the associated fragments of vesicular basaltlike material, it is the author's opinion that the objects are volcanogenic. If volcanism formed these objects, then the controversy exists as to whether they are due to explosive eruptions into the atmosphere or due entirely to submarine volcanic processes.

\section{Acknowledgements}

Dr. J.Hawkins, of Scripps Institution of Oceanography, carried out X-ray diffraction studies on the above material.

\section{References}

Glass, B. P., 1967. Microtektites in deep-sea sediments. Nature. 214, 374.

Glass, B. P., 1968. Glassy objects (microtektites?) from deep-sea sediments near the Ivory Coast. Science. 161,891 . 